\title{
Clarence, Claudio, and Hamlet: "The Dread of Something After Death"
}

\author{
DANIEL E. VAN TASSEL
}

My focus is the theme of preparing for death in Measure for Measure and Hamlet. These two plays, while veering apart generically, come within three years of each other in composition and share a preoccupation with the idea of death. For the hero of Hamlet the experience of death is tragic, since it is an unavoidable consequence of Hamlet's doing a deed that simultaneously ennobles him and sets the world aright. Like certain of Shakespeare's other comedies and romances, Measure for Measure is constructed on a comic curve that prevents real death from happening and produces its sense of an enlarged human potential for goodness by sustaining the illusion of death till the end, when, by a surprising reversal, life and happiness are reasserted. In both, progression toward death defines in the principal characters the values they ultimately esteem. When the characters accept the fact of death - theirs or that of an intimate - the plays reach their finale. In examining the preparation for death theme in these representative plays from Shakespeare's period of great tragedies and bitter comedies and, for comparison, in the earlier episode of Clarence's death in Richard III, my concern will be to show how Shakespeare follows and departs from the orthodox pattern of salvation richly outlined in The Book of Homilies and in the Christian tradition of ars moriendi. ${ }^{1}$

$$
* \quad * \quad *
$$

An important part of the characters' preparation lies in their expression of fear at the imminence of death, which takes the primary form of nightmares or similarly soul-shaking visions of the state beyond the grave. Quite understandably, when a character faces the prospect of the grave, his deepest fears and hopes come to the forefront. According to both Stoic and Christian attitudes, how one faces death tells most truly how one has lived. Montaigne asserts, "To philosophie, is to learne how to die."2 In "An Exhortation against the feare of Death," one of the earliest sermons in The Book of Homilies, we are told that "there be three causes wherefore men doe commonly feare death. First, the sorrowfull departing from worldly goods and pleasures. The second, the feare of the pangs and paines that come with death. Last and 
principall cause is, the horrible feare of extreame misery, and perpetuall damnation in time to come." 3 The sermon goes on to comment on "the bodily death" and "the second death," drawing the analogies of death as a sleep, rest as everlasting felicity, and second death as hell. It holds that death is the occasion for the soul's separation and departure from the body.

In Shakespeare we see the stamp of such Christian views of death. The fear of death his characters experience can be, and is for some, subdued by confession (not necessarily before an actual priest, however) and, as in the case of Hamlet and to a lesser extent Claudio, by a serene acceptance of certain facts - the painful condition of this life, the universality of death, and the natural or, particularly for Hamlet, providential design which carries life to completion in death (or ultimately to resurrection after death). While the plays do not extend beyond existential considerations that we all are wont to brood upon, they gain authenticity by incorporating into their depiction of human experience a world-view profoundly colored by the Christian tradition. ${ }^{4}$ Like their predecessors, the mystery and morality plays, Shakespeare's plays include in their scope of human preoccupations the fundamental questions of how one meets death and what one meets in death. But, unlike Everyman, the plays of Shakespeare, though they carry us to the graveside, do not, except in the spoken imaginations of characters who are forced to face death suddenly, explore the regions beyond this world. The paradise on earth is marriage and reconciled life in the comedies and eulogy and promise of a good name or an honorable story in the histories and tragedies. Horatio invites the celestial choir to sing his friend to blissful rest. In The Second Shepherds' Play and Everyman the angels advance and are seen and heard; in Everyman they take charge of the soul, transporting it "in to the heuenly spere," making a point along with the Doctor to remind the audience of the Christian promise of the body's final resurrection and of its reunion with the soul "Hye in heuen." That crown is not bestowed in Shakespeare's plays. But neither is it forgotten.

For Clarence, Claudio, and Hamlet, the sense of impending death is made more immediate by their being confined in a prison or prison-like situation. Death appears to be the only escape. The threat of death causes each to consider how he will meet it and to take imaginative stock of the mysteries that lie before him. Both Richard III and Measure for Measure, once the Duke takes leave and his proxy Angelo assumes temporary power, begin with a trip to prison. Clarence is conveyed to the Tower on orders from his suspicionridden king and brother Edward, and, unbeknownst to them, hastened to his death by the machinations of Richard. Claudio likewise is arrested and led to prison to be executed, his case intended by Angelo as a public lesson that the law can no longer be ignored with impunity. For Hamlet, Denmark and the whole contaminated world are one vast prison, "in which there are many confines, wards, and dungeons, Denmark being one o' th' worst" (II. ii. 243-45). ${ }^{6}$ More particularly, and of pivotal significance for the preparation 
for death theme, the imagery of confinement in Hamlet includes a voyage that Hamlet is forced to make. The ship is royally chartered to convey him to England for immediate execution. Hamlet's sleeplessness, the dark claustrophobic cabin in near proximity to the fatal commission, the untoward speed of his passage at the behest of his guilty and frightened uncle, the encounter with a pirate ship, his boarding it to become "their prisoner" (IV . vi. 20) - all bespeak the atmosphere of a prison cell or a nightmare that augurs certain death. But Hamlet's death is miraculously averted. Even his ingenuity seems a blessing from above. Evil designs yield before "heaven ordinant" (V. ii. 48). Hamlet's brush with death and the nature of his quick escape convince him that "There's a divinity that shapes our ends, / Rough-hew them how we will" (11. 10-11) and nurture in him an attitude of composure that will see him through his fatal mission. But to the results of his voyage I will have to return later.

In Christian thought the body is regarded as the prison of the soul, which is only released at death. ${ }^{7}$ But only the souls of godly men go to heaven, where they reside in everlasting felicity. When Clarence, Claudio, and Hamlet realize that they are at the threshold of death and begin to ruminate on what might follow, they initially take fright, but to avoid "second death" or damnation, they seek salvation and thereby win composure before death. As is evident in other of Shakespeare's comedies and romances, the death and resurrection paradigm informs the recovery of life, newly pardoned and leased, toward which the dynamics of Measure for Measure build. And, as we shall see, the apprehension of an afterlife exerts strong psychological pressure through the whole of Hamlet and in the episode of Clarence's death.

$$
* \quad * \quad *
$$

In Measure for Measure, where Shakespeare's treatment of preparation for death draws on both Montaigne and orthodox Christian doctrine, the temporary loss of hope is a prerequisite for the spirit of new life that is instilled at the end. ${ }^{8}$ Once the hope of escaping death appears to be gone for Claudio, the Duke can perform his saving work. And a major concern for the sentenced Claudio, concern expressed not only by Claudio but also by a group of intimates and well-wishers, is his preparation for death. His sister, as intercessor, seeks more time for him from Angelo, who adds to his villainy by giving orders to pinch further the victim's time before execution. Isabella begs a favor both spiritual and civil:

To-morrow? O, that's sudden! Spare him, spare him!

He's not prepar'd for death. Even for our kitchens

We kill the fowl of season. Shall we serve heaven

With less repect than we do minister

To our gross selves? (II. ii. 83-87). 
Her imaginative collapse of the quintessential distinction between body and soul is a rhetorical device. How much more care we should give our souls than our stomachs, she argues with wit and conviction. This argument follows her appeal on a higher level to the example of Christ as the perfect redeemer and incarnation of charity. Though Measure for Measure is a comedy, the issue of Claudio's being properly prepared for death is not an idle one. For the act of pardon and the gift of renewed life that are the beneficence of the play's final working out, the sparing of Claudio's and Angelo's lives and the further enrichment of those lives through marriage, depend on the characters' acceptance of appearances as realities. We are spared the illusions yet are drawn into a state of empathy with Claudio and Isabella and their suffering, which throughout is orchestrated for their good by the Duke. The play leads through death to resurrection.

A comedy is an action that ends happily, finishes better than it began, better than expected. ${ }^{9}$ Hopes are fulfilled at last. Claudio, as well as the Duke (till IV. ii), "hope[s] of pardon from Lord Angelo" (III. i. 1) but is realistic enough to begin to prepare himself for death in case his hopes are dashed. To the Duke, dressed and acting as a friar, he declares: "The miserable have no other medicine / But only hope: I have hope to live, and am prepar'd to die" (ll. 2-4). The Duke senses in Claudio's grasping for hope an uncertainty that belies his claim. It is better, he asserts, to "Be absolute for death," because such an attitude will result in the least disappointment: "either death or life / Shall thereby be the sweeter" (11. 5-6). The Duke can speak with comic assurance. He not only counts on Angelo to pardon Claudio but will and does, when necessary, step in to prevent disaster and promote the better life. Yet it is not just the Duke's added trust in the rightness of human nature or his power in reserve for effecting mercy that inspire the posture of equanimity he admonishes Claudio to develop. The spirit and much of the thought underlying his speech coincide with Montaigne and the Bible. A list of the commonplaces recited here from Montaigne can demonstrate how completely Shakespeare appropriated the essayist's philosophy of death. The most pertinent are the following: that our lives are ridiculously short in comparison with eternity or even, for that matter, the age of the world; that death is the order or cycle of nature and "the end of our cariere"; that death releases us from the miseries of life and old age as well as from our accumulated luxuries, which can weigh us down like excess cargo on our little trip through this world; and "that feare is more importunate and intolerable than death."

There is in the Duke's speech, moreover, a suggestion shared by Montaigne that the best cure for the fear of death lies in the contemplation of death. "Let us remove her strangenesse from her, let us converse, frequent, and acquaint our selves with her," Montaigne challenges those who are queasy in the company of death. The crux is that we are slaves when we try to turn away from death and freemen when we face it head-on: 


\section{2 / Renaissance and Reformation}

It is uncertaine where death looks for us; let us expect her everie where: the premeditation of death, is a forethinking of libertie. He who hath learned to die, hath unlearned to serve. There is no evill in life, for him that hath well conceived, how the privation of life is no evill. To know how to die, doth free us from all subjection and constraint. ${ }^{11}$

Christian thinking discriminates two deaths, one literal (or physical) and the other metaphorical (or spiritual). ${ }^{12}$ First comes the death of the body, which occasions the departure of the soul either to hell or to sleep to await resurrection and eternal life; "the second death" is eternal damnation, the thought of whose pains should strike terror deeper than that emanating from the pains accompanying physical death. It is the first or physical death that is spoken of in and out of the Bible as a sleep. Fully half of the Sermon on the Fear of Death is spent delineating the "rest" that will follow the physical death of the faithful, the rest promised to those rightly prepared to die. This rest is conceived as refreshment, as rest that, like our earthly sleep, restores us for our daily awakening, which parallels the felicity ushered in with the final resurrection. ${ }^{13}$

Admittedly, some Christian teachings regarding death are absent from the Duke-as-friar's sermon or essay on death. No specific references are made to the biblical concepts of death (both bodily death and second death) as the wages of sin, of death and its attendant pains as God the Father's "correcting rod," a phrase of signal importance in the Sermon on the Fear of Death, or of death as the means of the soul's unburdening itself of the flesh in order to enter into the state of continual bliss. The play ultimately stays this side of death. It is not a doctrinal statement, however persuasive a parable of human forgiveness, hope, and charity. The new life the characters receive at the play's close is analogous, not identical, to resurrection and carries the Duke's promise of "joy" in the here and now.

The Duke is a redeemer figure by virtue of his "Labouring to save ... life" (V. i. 391); he does work that assures new life in the place of the penalty of death. After he has revealed his disguise, ordered Angelo to marry Mariana, and pardoned Isabella, but before the ultimate test of Isabella's capacity for mercy, which is conducted while she is ignorant that her brother's life has been spared by the Duke, he speaks consoling words to her about her brother's death:

But peace be with him!

That life is better life, past fearing death,

Than that which lives to fear. Make it your comfort,

So happy is your brother (V. i. 396-99).

Coming from the Duke's perspective of wider knowledge, the words are ironic and comic. On the surface level they comprise a truism. In respect to their higher resonance they accommodate an eschatological reading (doubt- 
less the one Isabella gives to them). Also, in the comic context they are a version of the riddles which the superior intelligences of the comedies Rosalind, Friar Francis, Prospero, and the others - contrive and then seek to unravel.

Though her speech frequently has a biblical cadence, Isabella is found wanting when she paraphrases Montaigne at one point to belittle her brother for cowardice:

\section{Dar'st thou die?}

The sense of death is most in apprehension, And the poor beetle that we tread upon In corporal sufferance finds a pang as great As when a giant dies (III. i. 76-80).

Ironically, although Isabella vows to "fit his his mind to death, for his soul's rest" (II. iv. 187), she ends up unmercifully depriving her brother of even a short shrift. (Near the end, however, she grows in moral stature when at Mariana's request she kneels in intercession for Angelo's life.) Claudio strikes a truth when he retorts, "Death is a fearful thing" (1.115). But he vacillates in his preparedness for death. When hope exists of some release from his death sentence, no matter how frail or basely contrived that hope, Claudio clings desperately to it, and gives way to fear:

Ay, but to die, and go we know not where;

To lie in cold obstruction, and to rot;

This sensible warm motion to become

A kneaded clod; and the delighted spirit

To bathe in fiery floods, or to reside

In thrilling region of thick-ribbed ice;

To be imprison'd in the viewless winds

And blown with restless violence round about

The pendant world; or to be worse than worst

Of those that lawless and incertain thought

Imagine howling - 'tis too horrible!

The weariest and most loathed worldly life

That age, ache, penury, and imprisonment

Can lay on nature is a paradise

To what we fear of death (III. i. 117-31).

It is the loss of hope that finally makes him resolute for death. "Do not satisfy your resolution with hopes that are fallible" (11. 168-69), warns the Duke. Claudio's achievement of at least partial disdain for life is a necessary preparatory phase for his future estate, both the illusory one of death and the comic one of pardon and marriage. ${ }^{14}$

While it is true that the sentiments expressed in the Duke's "Be absolute for death" speech are not distinctly Christian, they can hardly be considered anti-Christian. ${ }^{15}$ It should be noted, furthermore, that the Duke, as friar, has 
not finished his task of preparing Claudio to die with this speech. It is but one phase of the preparation. After all, the Duke ends his counseling session with Claudio by saying he will return ("Dear sir, ere long I'll visit you again."), which he does after Isabella has assured her brother in a nearly unforgivable speech and leavetaking that she will "pray a thousand prayers for thy death, I No word to save thee" (11. 145-46). Both Claudio and his sister in very different ways set aside their concerns for his salvation. At death's door, Claudio craves life at the cost of $\sin$. He is thus courting his damnation. Isabella, in the extremity of a situation parallel to but more immediately final than death, is shocked by her brother's desperate argument, an echo of Angelo's unsaintly proposition that she lay down her honor. She vents her revulsion in wishing Claudio dead. That action more than any counsel of the Duke's results in Claudio's becoming "absolute for death." The Duke's last words to Claudio while the death sentence is allowed to hover over him complete the preparation for Claudio's properly approaching death: "Go to your knees, and make ready" (11. 169-70). No exhortation could be more Christian, more orthodox.

Recognition by Claudio of his apparently hopeless state then moves him to seek pardon and fix his mind to death. When we next see Claudio it is the Provost who, like a priest or gentler version of the hangman, having in a short soliloquy immediately beforehand expressed his continued pity for Claudio, reminds him of the urgency of his situation: "'Tis now dead midnight, and by eight to-morrow / Thou must be made immortal" (IV. ii. 64-65). He breaks off to inquire after his other, unpitied charge, Barnardine, whom Claudio reports to be fast asleep in his cell - a return to the idea of sleep as death and waking as the last judgment and resurrection; the figure proving grimly humorous later in lines spoken to the unprepared Barnardine by Pompey plying his new trade: "awake till you are executed, and sleep afterwards ... for he that drinks all night and is hang'd betimes in the morning, may sleep the sounder all the next day" (IV. iii. 32-33, 45-47). Before waking Barnardine, the Provost turns to Claudio in charity, bidding him "go, prepare yourself" and wishing him well ("Heaven give your spirits comfort!"). At which moment, as if in answer to the Provost's sincerest hopes for the arrival of "some pardon or reprieve / For the most gentle Claudio" (IV. ii. 71-72), the Duke enters again in his continued disguise as a holy father. In the unmuffling scene the Duke brings the pardoning to completion. Reunion and matrimony are the rewards granted to the characters of the comedies and romances who have undergone and benefited from their ordeals.

Claudio is hardly a mirror image of the man in the treatises on dying well who, after having been given heavy instructions, surrenders his soul cheerfully. For a time during his imprisonment he definitely and poignantly, out of much self-pity, succumbs to the temptations to unbelief, despair, and love of the world and his own flesh. But he ends up resisting and overcoming their 
permanently detrimental and damning powers through the ministrations of the Duke. The devils and angels of the popular woodcuts accompanying the text of the ars moriendi do not appear. Nor is Claudio's catechism orthodox. And while he receives advice on how to die and to pray and is prayed for, he is not instructed to meditate on the passion and crucifixion of Christ. Most conspicuously, Claudio's career departs from the traditional pattern of the ars moriendi in the fact that he does not die. The life he is granted, or spared to live, is not everlasting life. His salvation, for all its Christian echoes, follows comedy's formula, which is to celebrate unity and love in marriage.

In Measure for Measure, recognition of the need and value of forgiveness, which earns the characters their taste of joy and love in this world, is validated by the development of their respective attitudes toward death. After he has wrestled with the angel of death, Claudio is "pardoned" by the Duke to become the husband and near-father he should be. Isabella forgives the man who tried but, as she knew, failed (by the bed trick) to wrong her virginity and who lied to her in his promise not to put her brother to death. Angelo spreads the pall of death over the play; the Duke removes it but only when its deepest effects have furnished a basis for better life. Only then are they ready to be surprised by joy.

$$
\text { * * * * }
$$

In Shakespeare the bad dreams that disturb one's rest are analogous to the hellish fate guaranteed upon death to those who die ill-prepared. As Richard is an embodiment of the devil, so his nocturnal restlessness that deprives Anne of sleep is a symbolic extension of his capacity for the destruction of innocence. Clarence's dream, like the "timorous dreams" (IV. i. 84) and final ghostly nightmare of Richard, can be explained as the product of a bad conscience. Clarence's dream centres on a perilous voyage on which he drowns but does not die; he retains his perception and bodily senses during the descent to "the bottom of the sea" (I. iv. 28):

often did I strive

To yield the ghost; but still the envious flood

Stopp'd in my soul, and would not let it forth

To find the empty, vast, and wand'ring air,

But smother'd it within my panting bulk,

Who almost burst to belch it in the sea. ...

No, no, my dream was lengthen'd after life (11. 36-43).

Death pangs, according to the orthodox Christian viewpoint, ought to effect the separation of the soul from the body. But in Clarence's dream, where they are protracted and ineffectual, they mirror his earthly imprisonment from which there will be no escaping. In his vision of the hereafter Clarence is brought face to face with the ghosts of his past "misdeeds" 16 and then is 
subjected to the torments of hell. When he awakens from the brief and belated sleep that comes after his recounting the terrible nightmare that had taxed his earlier slumbers, his prophetic dream is in fact enacted. The two murderers, commissioned to their deadly mischief by the brother who in the dream is responsible for Clarence's drowning (prefiguring the fate of the malmseybutt), command him to "prepare to die" (1.180). Alluding to teachings from Scripture, Clarence in condemning their intended murder ironically pronounces doom on himself. The murderers, hardened though they be, allow him time to prepare for death - another instance in the plays of the paramount importance of last rites - and actually conduct the priestly function themselves, urging him to confess and "Make peace with God" (1. 249). By contrast, in Hamlet, where Claudius' damnation is an integral part of the revenge plot, Hamlet will not kill the King at prayer but waits for a time when he is breathing deeply in criminal air. Clarence's eloquent pleas - he appropriates the priestly role and counsels them to avoid damnation - do not spare him his life but do result in the repentance of the Second Murderer, who vainly attempts to save him. Spun out with humorous and ironic reversals, this scene contributes to the larger pattern of guilt and nemesis enveloping the play and offers a parallel to the staged nightmare summoned by Richard's guilt on the eve of the fatal battle that, in accord with Tudor myth, saw England victorious under God.

Clarence, who is as gullible as Richard is deceitful, is not innocent of blood. His better judgment, which in his waking life is repressed by his naive belief that Richard has his best welfare in mind, surfaces in his dream in the detail of Richard's deliberately contrived accident that sends him headlong "Into the tumbling billows of the main" (1. 20). But while Richard, in "the manifest-content," as Freud would phrase it, ${ }^{17}$ is the agent for his brother's death, it is Clarence's own guilt, a formidable and major part of "the latentcontent," which prompts the hideous journey of the soul toward Hades:

O then began the tempest o my soul!

I pass'd (methought) the melancholy flood,

With that sour ferryman which poets write of,

Unto the kingdom of perpetual night (11. 44-47)

Here and elsewhere in Shakespeare's glimpses into the hereafter the landscape of hell takes on the classical detail of the river Styx and is characterized by chaotic, howling winds and surging waves:

a legion of foul fiends

Environ'd me, and howled in mine ears

Such hideous cries that with the very noise

I, trembling, wak'd, and for a season after

Could not believe but that I was in hell,

Such terrible impression made my dream (11. 58-63). 
The Faustus-like vision of hell that Clarence experiences is a foretaste of his destiny should he die without having confessed and repented his sins. The dream represents both his longing to be relieved of the burden of guilt by accepting punishment without having to make confession and his desire to live and remain with his family. ${ }^{18}$

The prison scene is a sort of dramatic conceit. Clarence's sleep (a counterfeit of death) brings first a dream of his bodily death (for which the traditional metaphor is sleep and the archetype a journey) and then a simulation of his "second death" or eternal damnation. In terror, he awakes and confesses. Then, with a composure akin to that "rest" promised by the Bible to the godly man after death, he falls asleep again, only to awaken for the last time. The scene is, in effect, an enactment of Judgment Day. Its theme is the preparation for death. Richard's damnation, traced in the victory of his deeds over his conscience, is prefigured in the immediate cause of Clarence's concern for his own salvation.

$* \quad * \quad *$

C.S. Lewis rightly observed that "death is the subject of Hamlet"; and he argued that its manifestation there differs from its presence in the other tragedies. For the other heroes, "as for their author while he writes and the audience while they watch, death is the end. ... They think of dying: no one thinks, in these plays, of being dead. In Hamlet we are kept thinking about it all the time, whether in terms of the soul's destiny or of the body's." I agree with Lewis that "the fear of death; not ... a physical fear of dying, but a fear of being dead," is basic to Hamlet's characterization. ${ }^{19}$ But I wish to argue that it is the starting point only, not the finish of his career. For it is important to bear in mind that the "To be, or not to be" soliloquy, with its preoccupation with the "sleep of death," with its outrage at the "dreams" that will ensue (clearly a metaphor for the soul's distress in afterlife), with its sobering recognition of "the dread of something after death, / The undiscover'd country, from whose bourn / No traveller returns," occurs near the beginning of Act III. At this point in the play Hamlet had not caught the King's conscience, shed any blood, browbeaten and confessed his mother, thwarted the King's first plot on his life, or returned to home soil fully ready to complete the task of revenge.

From the outset Hamlet has had to bear up against the fact of his father's death. When the ghost of his dead father visits, he is brought face to face with a creature from the grave, and is privileged to hear and discern at least a fraction of the horrible secrets of its "prison-house." The elder Hamlet's having been

Cut off even in the blossoms of my sin,

Unhous'led, disappointed, unanel'd,

No reck'ning made, but sent to my account

With all my imperfections on my head (I. v. 76-79), 
is a wretched fact underlining the entire play. For us, as for Hamlet, to remember the ghost, who himself requests remembrance, is to remember his purgatorial state. He is

\footnotetext{
Doom'd for a certain term to walk the night, And for the day confin'd to fast in fires,

Till the foul crimes done in my days of nature

Are burnt and purg'd away (11. 10-13).
}

That stark thought haunts the play.

Yet the ghost is only one of several demonstrations in the play of persons going to their grave ill-prepared. Gonzago in the Mouse-trap play suffers a fate identical to that of Hamlet's father. Polonius meets instant death at Hamlet's hand. And if we depend on Hamlet's statement to learn whether the old counselor's soul went up or down, we are left with a question rather than a verdict. "They say 'a made a good end" (IV. v. 185-86), the mad Ophelia entones in a speech containing pathetic fallacy. The song she sings, "The Merry Milkmaids' Dumps," is both a denial of the second resurrection and an expression of pity for her father's spiritual state: “ 'God 'a' mercy on his soul!' / And of all Christians' souls, I pray God. God buy you” (11. 199-201). The obscurity of Polonius' funeral, however, may not so much imply an ungracious ending as reveal the court's caution over appearances. Rosencrantz and Guildenstern are twin instances of untimely death. Through Hamlet's adroitness they are "put to sudden death, / Not shriving time allow'd" (V. ii. 46-47). Nearly coincident with their deaths is Ophelia's. Her ending by drowning, to the degree that it was her own deranged doing, entitled her only to "maimed rites" (V. i. 219). That she is deprived of a proper church burial creates a sore point for her brother. The "churlish" priest whom Laertes insults - "A ministering angel shall my sister be, / When thou liest howling" (11. 240-42) - claims that he had done all that could be done for her, considering the nature of her death. He does not number Ophelia among "peace-parted souls" (1.238) and therefore enjoins no human or angelic choir to guide her to a deserved "rest."

The state of the King at the point of death is unequivocally clear: he remains guilty. Not only is his Cain-like murder unrepented but he has done all he could to engineer the final carnage and is implicated even in Gertrude's death. The mother's death is something more than gratuitous motivation for Hamlet's killing the King. Her case, by the way, is unclear. Unwittingly she begs forgiveness moments before she tastes death, admitting her intention of doing something her husband has just countermanded, she thinking that something a trifle: "I will, my lord, I pray you pardon me" (1. 291).

Next to Hamlet Laertes dies best. He succeeds in both avenging his father's death and winning forgiveness of Hamlet. Fortunately he does not die caught 
by the uncharitable oath he shouts at Hamlet while they tussle in Ophelia's grave - "The devil take thy soul!" (V.i. 258), to which Hamlet replies in dead earnest, "Thou pray'st not well" (1. 259) - or by the sham pardon he grants Hamlet before their mortal duel. But sensitive to the wrong and unsportsmanlike advantage he has taken of his opponent ("it is almost against my conscience"), Laertes, when the lengths of the King's treachery are exposed seeks Hamlet's forgiveness. Moments before they die their brotherhood is reestablished. It exonerates both and thus fits them for a good death. ${ }^{20}$.

The foiling by Hamlet of the King's plot on his life marks a stage in his preparation for death. Irony and anticipatory courage inform Hamlet's response to his uncle's plans for his exile in England (in IV. iii). The trip bears trappings of the archetypal voyage to extinction. The ostensible destination is England; the secret destination, which Hamlet intuits, is death. Claudius boldly urges Hamlet to "prepare" to depart, in his mind savoring the double nature of that trip he has arranged. Moments before the King gives packing orders to Hamlet, there is an exchange between them in which Hamlet playfully half-confesses the deed of his having killed Polonius. Questioned a second time about Polonius' whereabouts, Hamlet answers in terms that reverse those that Claudius uses to tell Hamlet to embark for England: "In heaven, send thither to see; if your messenger find him not there, seek him i' th' other place yourself. But if indeed you find him not with in this month, you shall nose him as you go up the stairs into the lobby" (IV. iii. 33-37). Hamlet's directions to Claudius are half-veiled threats on his life. They also declare his realization that his uncle is damned, a state that Hamlet will ensure follows him to the grave. The alternatives he presents for Claudius' finding the dead Polonius turn wittily on the distinction between, and final separation of, body and soul.

The question of how long it takes a corpse to rot and become a skeleton is raised in the churchyard scene. This scene, which follows in the wake of Hamlet's nearly miraculous return from the vessel bound for England and his death, is more than a tableau emphasizing memento mori. ${ }^{21}$ It continues themes broached in Hamlet's speech about Polonius' being "at supper" (1. 17). The three successive skulls upon which Hamlet descants provide graphic reinforcement of mutability. Hamlet's spoken words, his gestures, and the stage props all tell us he has accepted the fact of death. The scene in the churchyard serves as a symbolic announcement that the day of judgment is imminent. It is as if the tombs were opening: skulls are being exhumed, and live men are climbing in and out of the grave, first to dig and then to fight over a freshly but poorly-buried corpse. The movement reaches near chaos with the grief-stricken Laertes' suicidal demand of the funeral party to "pile your dust upon the quick and dead" (V.i. 251). The scene thus adumbrates the final leveling that is shortly to come. 
Unlike Faustus', Hamlet's death is pictured by the survivors as a departure from the world of sin and an entry into the kingdom of rest. Inspired by Hamlet's dying words, "The rest is silence" (V. ii. 358), Horatio bids farewell to his friend whose voice is stilled forever, asking "flights of angels" to "sing thee to thy rest!" (1. 360). ${ }^{22}$ Fortinbras gives the equivalent in this world of Hamlet's eschatological wishes in his command for the military salute ending the play. Hamlet's last words are richly ambivalent. For him, death is a cessation of life and its sounds of activity, of hearing news or giving voice to thoughts. Another will have to "report" him, his appointed confidant and executor Horatio, whom he entreats not yet to seek "felicity." Hamlet's words confirm that his life was well-lived and his death came after adequate preparation, for they look to a quietness beyond the grave that could not be his father's nor, by design, his uncle's. "Rest" has such resonance when registered in Horatio's eulogy.

Shakespeare does not insist on our traveling outside the borders of the dramatic experience that ends with the play. Through the steps preparing for it, Hamlet's death is portrayed in the context of Christian notions of living and dying. The play itself traces the orthodox stages of preparation and final acceptance of death: from dread of dying, to contemplation of death, to an understanding of death as a release from pain, to a full confession and repentance, a spirit of forgiveness, a renewed commitment to duty (a variation of the penitent's pledge to amend his wicked ways), and, finally, a serene acceptance of the imminence and rightness of death (the belief that "the readiness is all" and the composure that is afforded through belief that Heaven ordains all). I agree with Roland Frye that "For Hamlet, the context of readiness is essentially and explicitly Christian." 33 I am altogether at odds with Roy Battenhouse, who sees Hamlet as a "Black priest" enacting "a tragic perversion of Christian mysticism." ${ }^{4}$ The idea of a soldier remaining at his post till his tour of duty is ended, his mission accomplished, as Helen Gardner suggests, underlies the play as both fact and Christian metaphor ${ }^{25}$ The character and career of Hamlet can be partially explained by the Christian paradigm of preparation for death. Hamlet is not a version of Everyman. Yet it shares with the morality play a preoccupation with the terms of salvation and the proper preparations for dying. In a primary sense, its affinity with the genre of the revenge play accounts for the emphasis on damnation for the central villain. ${ }^{26}$ Ultimately, however, it is the apprehension of an afterlife that adds moment and urgency to the dramatic situation.

Shakespeare's treatment of the theme of death and dying incorporates Christian elements and evokes parallels with the ars moriendi tradition. One aspect of this vast theme is how death or an experience symbolic of death, such as separation caused by banishment or feigned death, impinges on the lives of the characters and transforms their values. In the plays we have examined - Measure for Measure, Richard III, and Hamlet - those properly 
prepared to die are those whose "dread of something after death" has helped to galvanize their move toward pardon. Only then, like the redeemed, are they ready for whatever life remains to them.

\author{
Muskingum College
}

\title{
Notes
}

1 For surveys of the ars moriendi tradition, see Nancy Lee Beaty, The Craft of Dying: A Study in the Literary Tradition of "Ars Moriendi" in England, Yale Studies in English, No. 175 (New Haven: Yale Univ. Press, 1970) and Sister Mary Catharine O'Connor, The Art of Dying Well: The Development of the Ars moriendi, Columbia Univ. Studies in English and Comparative Literature, No. 156 (New York: Columbia Univ. Press, 1942).

2 All citations from Montaigne are from The Essayes of Montaigne, trans. by John Florio [1603] (New York: Modern Library, n.d.), most of them from the essay whose title line is here quoted (pp. 48-63).

3 Popularly referred to as The Book of Homilies or simply the Homilies, the mid-sixteenth century, two-volume, collaborative and stridently Protestant work Certaine Sermons or Homilies appointed to be read in Churches, In the time of the late Queene Elizabeth of famous memory (1623; facsimile rpt. Gainesville, Florida: Scholars' Facsimiles and Reprints, 1968), was immensely influential. There is little point in disputing the argument by John Henry de Groot, The Shakespeares and "The Old Faith" (New York: King's Crown Press, 1946), pp. 150-57, that since they were required reading from the pulpits of all English churches, these sermons would have been heard by Shakespeare at Holy Trinity Church in Stratford where the family worshipped. Peter Milward, Shakespeare's Religious Background (Bloomington: Indiana Univ. Press, 1973), pp. 115-43, assesses the homiletic elements and finds influence not only of The Book of Homilies but also of the sermons of Henry Smith and of Laws of Ecclesiastical Polity by Richard Hooker.

4 G. Wilson Knight - whose criticism, despite occasional lapses into the esoteric or the politically reductive, I find illuminating - is certainly right, in Shakespeare and Religion: Essays of Forty Years (New York: Barnes and Noble, 1967), in claiming that "Shakespeare composes from a mind saturated in orthodox tradition; he can call on it whenever he wants to; medievalism is alive in imagery and thought." Concerning Shakespeare's Renaissance bearings, Knight notes that the plays express "a transitionally inclusive view covering two cultural periods" (p. 21).

5 The two quotations from Everyman (11. 899 and 917 ) are from the edition by A.C. Cawley (Manchester: Manchester Univ. Press, 1961).

6 All quotations from Shakespeare's plays are from The Riverside Shakespeare, ed. by G. Blakemore Evans et al. (Boston: Houghton Mifflin, 1974).

7 On the popularity and antiquity of the belief that the soul is released from the body at death, see Theodore Spencer, Death and Elizabethan Tragedy: A study of Convention and Opinion in the Elizabethan Drama (Cambridge: Harvard Univ. Press, 1936), especially pp. 10-13, 48, 99-103, 143. Milward also has convincingly shown that the characters of Shakespeare recognize the separation of body and soul at death (pp. 245-59). In Everyman this separation occurs at the end: "Now thy soule is taken thy body fro" (1. 897).

8 There are numerous studies of the biblical content of Measure for Measure, but to my mind the best is by Arthur C. Kirsch, "The Integrity of Measure for Measure," Shakespeare Survey, No. 28 (Cambridge: Cambridge Univ. Press, 1975), 89-105. Kirsch points to the parable of the talents as a strong influence on the play; and in treating "the idea of felix culpa," he asserts, "Tragic experience is not merely the prelude to comic salvation in Measure for Measure but the means by which such salvation can be understood and achieved" (105).

9 Northrop Frye, A Natural Perspective: The Development of Shakespearean Comedy and Romance (New York: Harcourt, Brace and World, 1965), though not in basic disagreement with such a definition, prefers to see comedy as a structure whose "logical end is festive," whose action leads to the rejuvenation of society. The quoted phrase occurs on p. 46, but see the full discussion in Chapter 3 , "The Triumph of Time," pp. 72-117. 


\section{2 / Renaissance and Reformation}

10 Florio. All the quotations and concepts listed except the last quotation are from Montaigne's essay "To Learn How to Die," the last one occurring in his essay "Of Feare," p. 45. For the expression of similar sentiments, see also his next essay "That We Should Not Judge of Our Happinesse, Untill After Our Death," pp. 45-48, and the last pages of "An Apologie of Raymond Sebond."

11 Florio, p. 53.

12 The sermon "An Exhortation against the feare of Death," from The Book of Homilies, gives a very clear explanation of this Christian concept of the two deaths. The concept is insisted upon in the medieval treatises on dying well. See, for example, The Book of the Craft of Dying, ed. by Frances M.M. Comper (London: Longmans, Green, 1917), which states: "Though bodily death be most dreadful of all fearful things, as the Philosopher [Aristotle] saith in the third book of Ethics, yet spiritual death of the soul is as much more horrible and detestable, as the soul is more worthy and precious than the body" (p. 5).

13 See also "The Order for the Burial of the Dead," in The Book of Common Prayer 1559: The Elizabethan Prayer Book, ed. by John E. Booty (Washington, D.C.: Folger Shakespeare Library, 1976), pp. 309-13, which is a compendium of scriptural passages and commentary on the mystery of death.

14 I would not want to claim with Spencer, however, that Claudio is actually "converted" (p. 115).

15 As Kirsch notes, "The contemptus mundi attitudes which he articulates ... were conventional premises of Christian faith" (98).

16 Which detail, as Marjorie B. Garber notes, Dream in Shakespeare: From Metaphor to Metamorphosis (New Haven: Yale Univ. Press, 1974), serves as "historical perspective" (p. 25).

17 The concepts are basic ones in Sigmund Freud, The Interpretation of Dreams, trans. and ed. by James Strachey (New York: Avon Books, 1965); see especially the chapter on "Dream-Work," pp. 311-546.

18 For an analysis of Clarence's dream quite different from mine, see Garber, who suggests that " "the dream-work' ... has rendered Clarence's latent supsicion of Richard, a suspicion he finds emotionally unbearable, into more reassuring terms" (p. 22).

19 "Hamlet: The Prince or the Poem?", Proceedings of the British Academy, 28 (London: Oxford Univ. Press, 1942), p. 149.

20 See Fredson Bowers, "Hamlet as Minister and Scourge," PMLA, 70 (Sept. 1955), 749.

21 See Roland Mushat Frye, "Ladies, Gentlemen, and Skulls: Hamlet and the Iconographic Traditions," Shakespeare Quarterly, 30 (Winter 1979), 15-28, for the rich visual tradition behind the scene.

22 Baldwin Peter, "Hamlet and In Paradisum," Notes and Queries, 3 (July 1952), 279-80, sees the line as an echo from the In Paradisum antiphon of the Roman Catholic services for the dead. Bowers calls the lines "Horatio's blessing" and "benediction for a minister of providence" (749).

23 Shakespeare and Christian Doctrine (Princeton Univ. Press, 1963), p. 138. See J.V. Cunningham Woe or Wonder: The Emotional Effect of Shakespearian Tragedy (Denver: Univ. of Denver Press, 1951) for the same point (pp. 11-12, 129). Ivor Morris, Shakespeare's God: The Role of Religion in the Tragedies (London: George Allen and Unwin, 1972), in commenting on Hamlet's biblical reference to the fall of a sparrow, states: "Hamlet's trust in Providence is therefore to be understood as belonging to that satisfaction of desire in the soul which betokens its homecoming in God - the recognition by the soul, at the journey's end, that it is God, and not itself, which has guided all its steps, and that all its steps have led it to Him. That this recognition is present in Hamlet in its fullness may be judged by the peculiar quality of his trust. For in it lies not only conviction, but repose" (p. 428).

24 Shakespearean Tragedy: Its Art and Its Christian Premises (Bloomington: Indiana Univ. Press, 1969), pp. 250, 264.

25 The Business of Criticism (Oxford: Oxford Univ. Press, 1959), pp. 48-49.

26 Gardner, pp. 41-46. 